\title{
Killing of Escherichia coli in the peritoneal cavity of convalescent mice; role of specific and non-specific immune mechanisms
}

\author{
J. VUOPIO-VARKILA and P.H. MÄKELÄ \\ National Public Health Institute, Mannerheimintie 166, SF-00280 Helsinki, Finland
}

\begin{abstract}
Summary. Mice surviving a sublethal $E$. coli $\mathrm{O} 18: \mathrm{K} 1$ infection possess a greatly increased resistance to a subsequent lethal $E$. coli $\mathrm{O} 18: \mathrm{K} 1$ peritonitis. A similar increase in resistance can also be achieved by LPS pretreatment. The early course of the infection in the convalescent mice at day 1 was identical to that in LPS-pretreated mice. At this time, the convalescent mice were also able to restrict the growth of the heterologous $E$. coli $\mathrm{O} 78(\mathrm{ColV})$ strain, suggesting that non-specific phagocyte activation was responsible for the increased destruction of the bacteria. At day 4 , the kinetics of infection in convalescent mice were identical to those in mice passively immunised with specific anti-K1 capsule antiserum. A rapid decline in the numbers of viable homologous, but not heterologous; bacteria took place in the peritoneal cavity suggesting effective antibody-mediated opsonisation followed by phagocytosis and killing of the bacteria.
\end{abstract}

\section{Introduction}

An intraperitoneal injection of E. coli $\mathrm{O} 18: \mathrm{K} 1$ in mice caused a rapidly developing peritonitis and septicaemia, and death within 24-48 h (VuopioVarkila et al., 1987a). However, if the challenge dose was small (c. $0 \cdot 1$ LD50; $\left.4 \times 10^{4} \mathrm{cfu}\right)$, the mice survived and were able to eradicate the bacteria from the peritoneal cavity within $24 \mathrm{~h}$. At this time the convalescent mice also showed an increased resistance to an otherwise lethal dose of $E$. coli (Vuopio-Varkila et al., 1987b). A similar increase in resistance to infection could be achieved by subcutaneous injection of a small dose of heterologous rough-type lipopolysaccharide (LPS)(VuopioVarkila et al., 1987b). In the LPS-pretreated mice, however, the destruction of bacteria started 3-4h after challenge, i.e., earlier than in the convalescent mice. As resistance to the new challenge could be observed as early as $24 \mathrm{~h}$ after the primary infection or LPS treatment, we concluded that it was most probably due to a non-specific activation of phagocytic cells (Parant, 1983; Vuopio-Varkila et al., 1987b).

The present study was undertaken to characterise the development of resistance in mice convalescing from $E$. coli $\mathrm{O} 18: \mathrm{K} 1$ infection and the roles of nonspecific macrophage activation and the specific immune response.

Received 11 Mar. 1987; revised version accepted 1 June 1987.

\section{Materials and methods}

\section{Bacterial strains}

For the standard mouse challenge we used $E$. coli strain IH 3080 (serotype $018: \mathrm{K} 1: \mathrm{H} 7$ ) (Vuopio-Varkila et al., $1987 a$ ), isolated from a case of human neonatal meningitis. In some experiments, other challenge strains were used (table I). All strains were stored at $-70^{\circ} \mathrm{C}$ in skimmed milk in small volumes until used. For injection, the bacteria were grown overnight in Luria broth (Miller, 1972) at $37^{\circ} \mathrm{C}$ on a rotatory shaker, the culture was diluted 10 -fold with fresh medium and grown for a further 120 min in similar conditions.

\section{Experimental infection}

$(\mathrm{CBA} \times \mathrm{C} 57 \mathrm{BL} / 6) \mathrm{F} 1$ hybrid mice (8-10 weeks old) bred at this Institute were used in all assays. The bacterial challenge (10-fold dilutions of exponential-phase bacteria in $0.2 \mathrm{ml}$ of saline) was injected intraperitoneally (ip). The LD50 was determined from the day 5 survival data for groups of 6 mice (Reed and Muench, 1938).

\section{Tissue counts of bacteria}

Samples were taken from the bacterial inoculum as well as from the peritoneal cavity for measuring the numbers of viable bacteria by plating out a series of 10 fold dilutions. Mice were killed by cervical dislocation, and the peritoneal fluid was harvested by injecting $2 \mathrm{ml}$ of saline ip and withdrawing $0.5 \mathrm{ml}$ after gentle massaging. The dilution factor was included in all calculations. 
Table I. E. coli strains used in this study

\begin{tabular}{|c|c|c|c|c|}
\hline Strain & Description & Isolated from & Used for & $\begin{array}{c}\text { LD50 } \\
\text { (cfu/mouse) }\end{array}$ \\
\hline IH3080 & $\mathrm{O} 18: \mathrm{K} 1: \mathrm{H} 7$ & neonatal meningitis & ip challenge & $4 \times 10^{5}$ \\
\hline IH 23265 & $\mathrm{O} 18: \mathrm{K} 5$ & neonatal meningitis & ip challenge & $3.6 \times 10^{6}$ \\
\hline IH3136 & $\mathrm{O} 1: \mathrm{K} 1$ & $\begin{array}{l}\text { septicaemia following pyelonephritis of a } \\
1 \text { month old boy }\end{array}$ & ip challenge & $2 \times 10^{6}$ \\
\hline $94141 / 78$ & O78(ColV) & $\begin{array}{l}\text { faeces of a septicaemic patient in Hungary; } \\
\text { received from Dr. H. Milch, National } \\
\text { Institute of Hygiene, Budapest, Hungary. }\end{array}$ & ip challenge & c. $3 \times 10^{6}$ \\
\hline
\end{tabular}

Each point in the figures represents the number of bacteria (cfu)/total volume of peritoneal fluid and is the geometric mean of results from three mice.

\section{Radiolabelling of the bacteria}

The bacteria were grown in Luria broth (Miller, 1972) overnight at $37^{\circ} \mathrm{C}$ with aeration, centrifuged $(3000 \mathrm{rpm}$, $10 \mathrm{~min}$ ) and diluted 40-fold in Davis's minimal medium (Miller, 1972) containing glucose $0.1 \% \mathrm{w} / \mathrm{v}$ and Luria broth $0.001 \% \mathrm{v} / \mathrm{v}$. They were grown in the same conditions to early logarithmic phase $(20$ Klett units, KlettSummerson colorimeter, red filter), when $100 \mu \mathrm{Ci}$ of ${ }^{35} \mathrm{~S}$ methionine (c. $1200 \mathrm{Ci} / \mathrm{mmol}$; Amersham Laboratories, Buckinghamshire) was added and growth continued to $50 \mathrm{Klett}$ units. The bacteria were then pelleted(Eppendorf centrifuge, $2 \mathrm{~min}$ ), washed twice and suspended in phosphate-buffered saline, $p \mathrm{H} 7 \cdot 4$ (PBS). The specific activity determined in a liquid scintillation counter was approximately $5 \times 10^{7} \mathrm{cpm} / 5 \times 10^{8}$ bacteria present in $1 \mathrm{ml}$ of the suspension.

\section{In-vivo phagocytosis of radiolabelled bacteria}

Mice were inoculated ip with $1 \times 10^{6}$ live bacteria $(1 \times$ $10^{5} \mathrm{cpm} /$ mouse $)$ in $0.2 \mathrm{ml}$ of PBS. A sample $(1 \mathrm{ml})$ of the peritoneal contents was then collected with PBS at different times, as described above. From a sample of $0.1 \mathrm{ml}$, the number of viable bacteria was determined by plating 10-fold dilutions on Luria agar. The total radioactivity recovered from the peritoneal cavity was determined from a further $0.1-\mathrm{ml} \mathrm{sample}$. A third sample $(0.8 \mathrm{ml})$ was centrifuged $(550 \mathrm{rpm}$ for $5 \mathrm{~min})$ to pellet the peritoneal cells and bacteria associated with them but to leave the free bacteria in the supernate. The specific activity of the samples was determined with a liquid scintillation counter. Each point shown represents the mean of the results from three mice.

\section{LPS pretreatment}

E. coli K-12 LPS, the same preparation used previously (Vuopio-Varkila et al., 1987b), was isolated by the phenolchloroform-petroleum-ether method (Galanos et al., 1969) and diluted in water, stored at $-70^{\circ} \mathrm{C}$ in small volumes and briefly sonicated before use. Mice were given subcutaneous (sc) injections of $5 \mu \mathrm{g}$ of $E$. coli $\mathrm{K}-12$ LPS in $0 \cdot 1 \mathrm{ml}, 24 \mathrm{~h}$ before bacterial challenge.

\section{Passive immunisation}

The $\mathrm{K} 1$ capsule-specific hyperimmune serum from a horse (H46) immunised with Neisseria meningitidis group B was a gift from Dr J. Robbins, NIH, Bethesda, MD, USA. Mice were given an ip injection of $0.2 \mu \mathrm{l}$ of inactivated $\left(56^{\circ} \mathrm{C}, 30 \mathrm{~min}\right)$ anti-K 1 antiserum in $0.2 \mathrm{ml}$ of saline $2 \mathrm{~h}$ before challenge.

\section{Results}

\section{Kinetics of E. coli $O 18: K 1$ infection in convalescent mice}

Mice that had recovered from a sublethal $E$. coli O18:K1 infection were resistant to subsequent challenge with large doses of $E$. coli, up to 50 LD50 $\left(2 \times 10^{7} \mathrm{cfu}\right)$ (table II). This increase in resistance was observed as early as $24 \mathrm{~h}$ after the sublethal challenge (Vuopio-Varkila et al., 1987b) and persisted for at least 14 days. The resistance to infection in the convalescent mice was thus of longer duration than in LPS-pretreated mice, in which it did not

Table II. Mortality of convalescent mice from E. coli O18:K1 infection

\begin{tabular}{l|cc}
\hline Pretreatment & $\begin{array}{c}\text { Challenge dose } \\
\text { (day 0) }\end{array}$ & $\begin{array}{c}\text { Number of dead mice/ } \\
\text { total number challenged }\end{array}$ \\
\hline Sublethal $E$. coli & & \\
O18:K1 challenge & & \\
on $\quad$ day -2 & 5 LD50 & $1 / 12$ \\
& 50 LD50 & $3 / 9$ \\
day -4 & 10 LD50 & $0 / 6$ \\
day -7 & 10 LD50 & $0 / 6$ \\
day - 14 & 10 LD50 & $0 / 6$ \\
no pretreatment & 10 LD50 & $6 / 6$ \\
\hline
\end{tabular}


last for more than 4 days (Vuopio-Varkila et al., 1987b).

To study whether this difference was due to different mechanisms of bacterial elimination, the course of the infection in these mice was followed. When the convalescent mice were challenged with a 5 LD50 dose of homologous $E$. coli O18:K1 one day after the initial infection, bacterial growth in the peritoneal cavity was very similar to that in mice pretreated with LPS ( $5 \mu \mathrm{g}$ of $E$. coli K-12 LPS given sc $24 \mathrm{~h}$ before challenge) (fig. 1). One hour

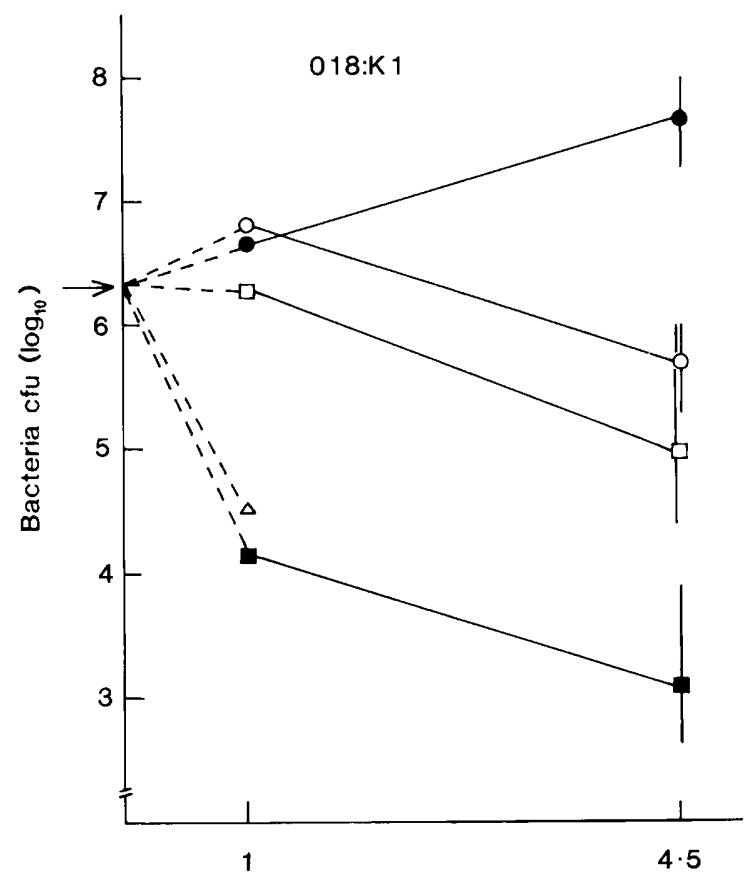

Time (h)

Fig. 1. Early kinetics of E. coli $\mathrm{O} 18: \mathrm{K} 1$ infection in the mouse peritoneal cavity. The challenge dose (5 LD50) is indicated by an arrow. Each point represents the geometric mean of results from three mice; the vertical lines show the scatter between the results. Normal mice 0 , day -1 convalescent mice $\square$, day- 4 convalescent mice $\square, \mathrm{K}-12$ LPS-treated mice ( $5 \mu \mathrm{g}$ of LPS sc $24 \mathrm{~h}$ before) $O$, antiserum-treated mice $(0.2 \mu \mathrm{l}$ of anti-K1 antiserum $2 h$ before) $\triangle$.

after injection, the numbers of bacteria recovered from the peritoneal cavities of these mice were similar to those in control mice, whereas at $4.5 \mathrm{~h}$, both the day 1 convalescent and the LPS-pretreated mice had c. 100-fold fewer viable $E$. coli in their peritoneal cavities than did the controls.

If the time interval between the sublethal $E$. coli $\mathrm{O} 18: \mathrm{K} 1$ infection and the challenge was increased to 4 days, the course of infection was completely different. By $1 \mathrm{~h}$ after challenge, a dramatic drop was seen in the numbers of bacteria recovered from the peritoneal cavities of the convalescent mice, showing that only c. $1 \%$ of the inoculum was viable (fig. 1). This rapid decline in live bacteria suggested effective opsonisation followed by killing of the bacteria. Indeed, the early course of infection in the day- 4 convalescent mice was similar to that in mice passively immunised with a protective amount of opsonising anti-K1 capsule antibodies (VuopioVarkila et al., 1987a) (fig. 1). A similar rapid elimination of the injected bacteria was seen in mice tested on day 14 or even day 52 of their convalescence (data not shown).

\section{Killing of bacteria in the peritoneal cavity}

To show that the reduction in bacterial numbers seen in the day- 4 convalescent mice was due to intraperitoneal killing of the bacteria, ${ }^{35} \mathrm{~S}$-methionine-radiolabelled $E$. coli $\mathrm{O} 18: \mathrm{K} 1$ was used as the challenge (fig. 2). The viable bacteria were determined as colony forming units (cfu) and the total bacteria as radioactivity (total $\mathrm{cpm}$ ) in peritoneal washings taken 30 and $60 \mathrm{~min}$ after challenge. The percentage of radiolabel found in the cell-free supernate of the peritoneal fluid (supernate cpm) was also measured. In a peritoneal sample drawn immediately after challenge, we could account for $98 \%$ of the radioactivity. This count was taken as the initial cpm $(=100 \%)$.

Most of the viable bacteria were eliminated from the peritoneal cavity by $30 \mathrm{~min}$, both in the mice pretreated with the anti-K1 serum and in the day- 4 convalescent mice (fig. 2A). The numbers of viable bacteria were reduced in the antiserum-treated and day- 4 convalescent mice to 4 and $12 \%$, respectively after $60 \mathrm{~min}$, while the total radioactivity was reduced much less, to $46-69 \%$ (fig. 2B). Most of the label was found to be associated with the phagocytic cells (fig. 2C) suggesting that the bacteria were rapidly opsonised and taken up by phagocytic cells capable of killing them. The slow reduction of radioactivity in the peritoneal cavity (to $c .55 \%$ in $60 \mathrm{~min}$ ) was most probably due to two factors, the escape of bacteria from the peritoneal cavity via lymphatic absorption (Dunn et al., 1985) and their adherence to the walls of the peritoneal cavity.

In untreated as well as day-1 convalescent and LPS-treated mice the numbers of viable bacteria decreased only slowly, at the same rate as radioactivity, during the first hour of infection, and at 30 min most of the label was found in the supernate of the peritoneal fluid, i.e., the bacteria had not been engulfed by the phagocytes (fig. $2 \mathrm{~A}$ and $2 \mathrm{C}$ ).

From the above data we tentatively conclude 


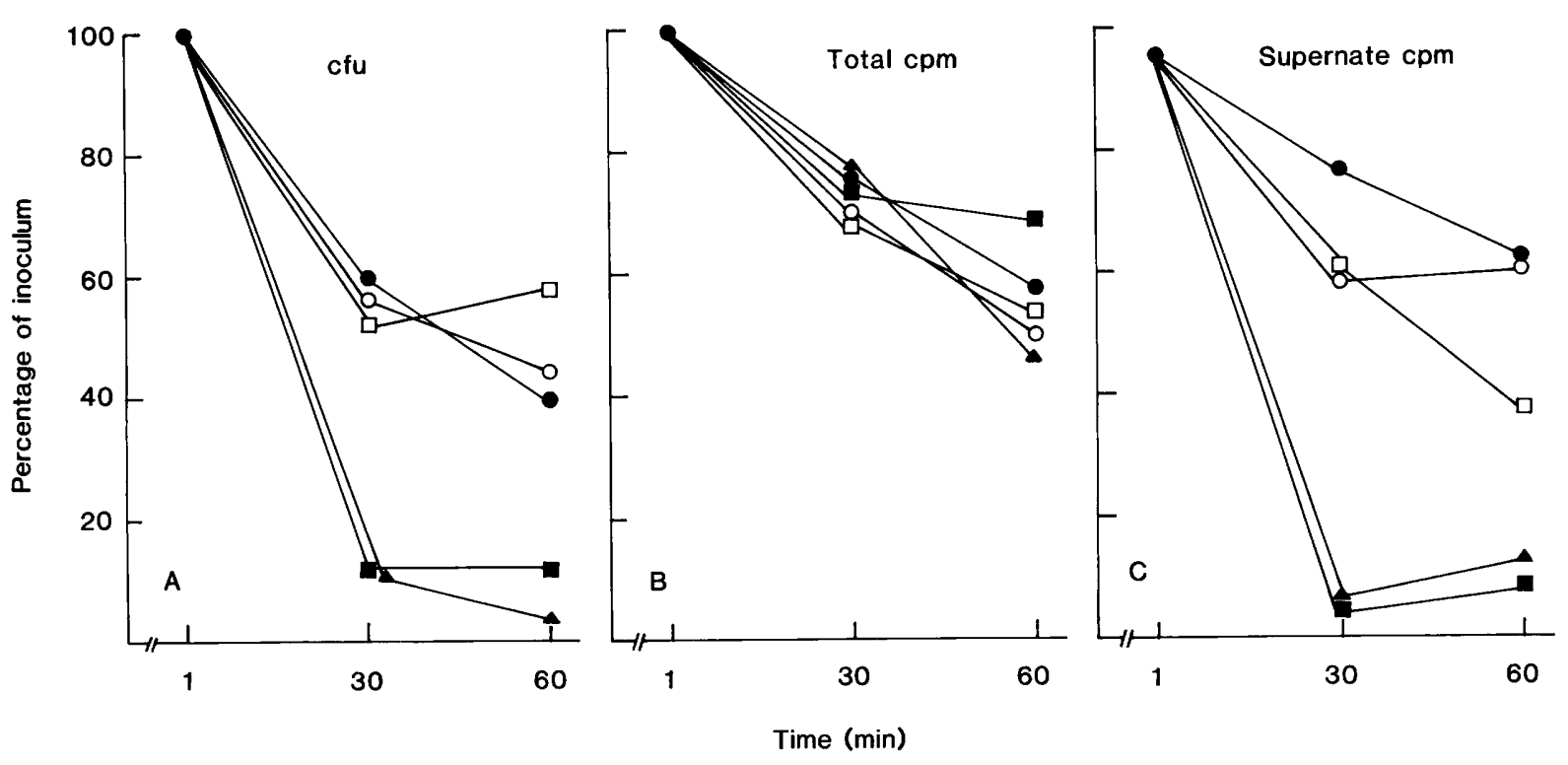

Fig. 2. The fate of ${ }^{35} \mathrm{~S}$-methionine-labelled $E$. coli $\mathrm{O} 18: \mathrm{K} 1$ in the peritoneal cavity after a $2 \cdot 5 \mathrm{LD} 50$ challenge. Numbers of viable bacteria (A), total radioactivity (B) and radioactivity found in the supernate (C) were measured from the peritoneal washings drawn from three mice; the points shown are means of the values. A sample drawn immediately after inoculation was taken to represent $100 \%$ for calculations. Normal mice 0 , day-1 convalescent mice $\square$, day-4 convalescent mice $\square$, LPS-pretreated mice (5 $\mu \mathrm{g}$ of K$12 \mathrm{LPS} \mathrm{sc} 24 \mathrm{~h}$ before) $\bigcirc$, antiserum-treated mice $(0 \cdot 2 \mu \mathrm{l}$ of anti-K 1 antiserum $2 \mathrm{~h}$ before $) \Delta$.

that the resistance to infection in the day-1 convalescent mice was due to macrophage activation, whereas in the day-4 convalescent mice, antibody-mediated opsonisation was prominent.

\section{Specificity of infection resistance in convalescent mice}

Because the two possible mechanisms of resistance, macrophage activation or antibody-mediated opsonisation, differ in specificity, an attempt was made to distinguish between them by challenging the convalescent mice with heterologous $E$. coli strains that shared either the $\mathrm{O} 18$ or the $\mathrm{K} 1$ antigen with the O18:K1 strain, or had neither of these antigens. Three mouse-virulent $E$. coli strains were used, all of which cause peritonitis and septicaemia in mice when injected ip at moderate $\left(4 \times 10^{6}-10^{7}\right.$ bacteria/mouse) doses.

Day-4 convalescent mice were resistant to the $\mathrm{O} 18$ and the $\mathrm{K} 1$, but not to the 078 bacteria. By contrast, the resistance in day-1 convalescent mice was non-specific, also encompassing the 078 strain. In the day- 4 convalescent mice, both E. coli $\mathrm{O} 18: \mathrm{K} 5$ (fig. 3A) and $E$. coli $\mathrm{O} 1: \mathrm{K} 1$ (fig. 3B) were rapidly eliminated from the peritoneal cavity during the first hour of infection (a drop of 1.5-2.1 $\log _{10}$ in $\mathrm{cfu})$. Growth of the heterologous, antigenically unrelated E. coli $\mathrm{O} 78$ (fig. 3C) strain was uninhibited for the first hour after challenge in both day- 1 and day-4 convalescent mice, and was subsequently eliminated from the day 1 but not from the day- 4 convalescent animals.

\section{Discussion}

Mice that had recovered from a sublethal $E$. coli infection were shown to be very resistant to a subsequent, otherwise lethal $E$. coli challenge. A similar increase in resistance could also be induced by LPS-pretreatment (Vuopio-Varkila et al., $1987 b$ ). When the course of $E$. coli infection was studied in the convalescent mice at different times after sublethal infection, we found that the infection kinetics of day-1 convalescent mice were identical to those of LPS-pretreated mice. At this time the convalescent mice were also able to restrict the ip growth of an unrelated, heterologous E. coli strain. Both of these observations suggest that non-specific phagocyte activation was responsible for the enhanced bacterial destruction. At day 4 the convalescent mice were able to rapidly reduce the numbers of viable challenge bacteria in the peritoneal cavities. A similar, efficient elimination of challenge organisms was observed in mice treated with anti-capsular antibody, suggesting that effective antibody-mediated opsonisation, phagocytosis 

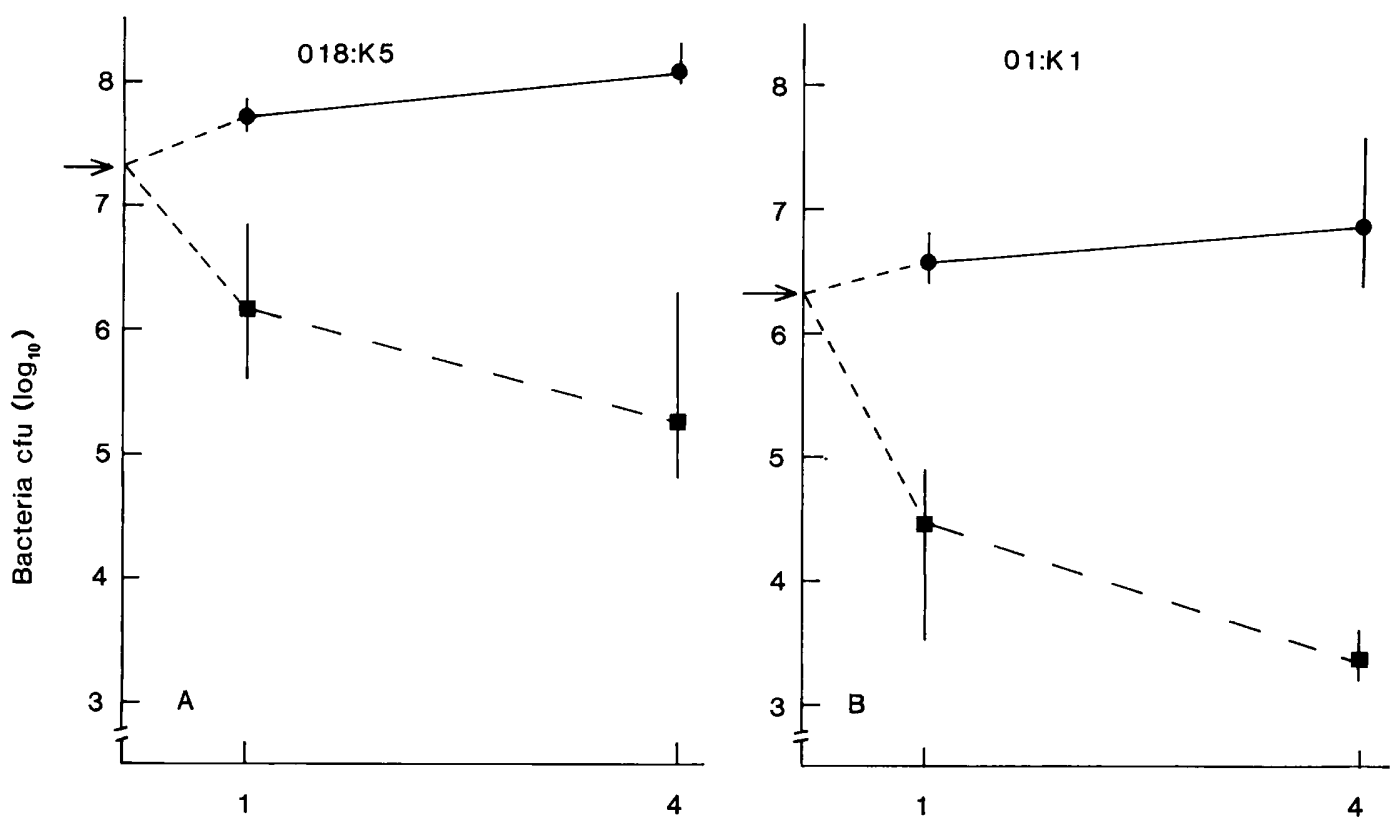

Time (h)

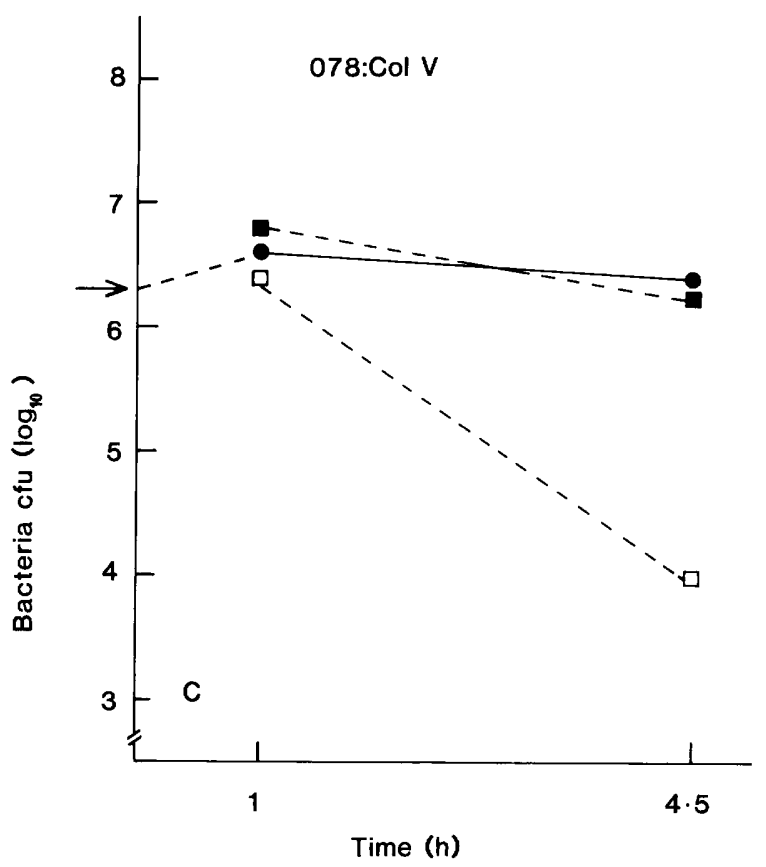

Fig. 3. Kinetics of E. coli O18:K5 (A), O1:K1 (B) and 078(ColV) (C) infections in the peritoneal cavity of normal mice 9 , day-1 convalescent mice $\square$, and day-4 convalescent mice $\square$. The challenge dose is indicated by an arrow. Each point represents the geometric mean of results from three mice; the vertical lines show the scatter between the values.

and killing of the bacteria occurred in the peritoneal cavities of day- 4 convalescent mice. Only antigenically-related bacteria, which shared a major cellsurface antigen (either $\mathrm{O}$ or $\mathrm{K}$ ), were eliminated in these mice.

Since the studies of Rowley (1955), Landy (1956) and Abernathy (1957) it has been evident that pretreatment with bacterial cell-wall components, in particular with LPS, can increase resistance to infection. The LPS-induced enhanced elimination of bacteria is due to non-specific systemic activation of phagocytes, especially macrophages (Galelli et 
al., 1977) and activation is of short duration, 4-8 days after the last LPS injection (Rowley, 1964; Tegtmeier and Andersen, 1983; Vuopio-Varkila et al., 1987b). In convalescent mice, however, the enhanced resistance lasted much longer. This suggested that either a sublethal $E$. coli infection was a stronger inducer of non-specific immunity or that additional defence mechanisms (e.g., antibodymediated killing) were involved.

For studying the early kinetics of $E$. coli infection in these mice we chose two times-day 1 and day 4 after the sublethal infection. On day 1 the increased resistance was most probably due to non-specific cell activation, because the specific antibody response had hardly had time to develop, whereas the LPS-mediated increase in resistance developed in $24 \mathrm{~h}$ (Vuopio-Varkila et al., 1987b). In day-4 convalescent mice the role of specific opsonising antibodies in promoting phagocytosis was evident. The kinetics of infection in the day- 4 convalescent mice were identical to those in antibody-treated mice. The observation that only antigenicallyrelated $E$. coli strains were eliminated from the day4 convalescent mice also suggested the importance of specific antibodies at this time. Consistent with this, we also found that the day- 4 convalescent mice were not resistant to lethal, systemic Salmonella typhimurium or Klebsiella pneumoniae infections (unpublished observation).

The peritoneal cavity of day- 4 convalescent mice was shown to be the site of the enhanced killing of the bacteria. The phagocytosis and killing of the capsulate $E$. coli $\mathrm{O} 18: \mathrm{K} 1$ bacteria, that are highly

\section{REFERENCES}

Abernathy R S 1957 Homologous and heterologous resistance in mice given bacterial endotoxins. Journal of Immunology 78: 387-394.

Dunn D L, Barke R A, Knight N B, Humphrey E W, Simmons R L 1985 Role of resident macrophages, peripheral neutrophils and translymphatic absorption in bacterial clearance from the peritoneal cavity. Infection and Immunity 49: $257-264$.

Galanos C, Lüderitz O, Westphal O 1969 A new method for the extraction of $\mathrm{R}$ lipopolysaccharides. European Journal of Biochemistry 9: 245-249.

Galelli A, Parant M, Chedid L 1977 Role of radiosensitive and radioresistant cells in nonspecific resistance to infection of LPS-treated mice. Journal of the Reticuloendothelial Society 21: $109-118$.

Horwitz M A, Silverstein S C 1980 Influence of the Escherichia coli capsule on complement fixation and on phagocytosis and killing by human phagocytes. Journal of Clinical Investigation 65 : 82-94.

Landy M 1956 Increase in resistance following administration resistant to complement-mediated killing (Horwitz and Silverstein, 1980; Vaara et al., 1984), were most probably due to effective in-situ opsonisation of the bacteria by antibodies directed to their cell-surface structures. At $30 \mathrm{~min}$ after bacterial injection, most of the radiolabel was found in the cell fraction of the peritoneal washings in both the day- 4 convalescent and the antibody-treated mice. Our attempts to show with EIA the presence of anti-capsular or anti-O18 LPS antibodies in the peritoneal washing of convalescent mice on days 4 or 7 have, however, failed (unpublished observations), probably because of low concentrations of antibodies present.

The mechanism by which the day-1 convalescent and the LPS-pretreated mice killed the injected bacteria is still obscure. The bacteria remained for several hours in the peritoneal fluid without association with phagocytic cells (fig. 2C). The total number of peritoneal exudate cells in the peritoneal washings of both day- 1 and day- 4 convalescent mice before challenge was increased, and the cells showed signs of activation (greater size, more granules), but the same was not true of LPSpretreated animals (Vuopio-Varkila, unpublished observations). The lag period between the challenge and killing of the bacteria suggests that recruitment of other effector cells might be required for efficient destruction of the bacteria in LPS-treated mice and we are currently trying to characterise these cells.

This study was supported by SITRA, the Finnish National Fund for Research and Development, and by the Academy of Finland. of bacterial lipopolysaccharides. Annals of the New York Academy of Sciences 66: 292-303.

Miller J H 1972 Experiments in molecular genetics. Cold Spring Harbor Laboratory, New York.

Parant M 1983 Effect of LPS on nonspecific resistance to bacterial infections. In: Nowotny A (ed) Beneficial effects of endotoxins, Plenum Press, New York, pp 179-196.

Reed L J, Muench H 1938 A simple method of estimating fifty per cent end-points. American Journal of Hygiene 27: 493497.

Rowley D 1955 Stimulation of natural immunity to Escherichia coli infections. Observations on mice. Lancet 1 : 232-234.

Rowley D 1964 Endotoxin-induced changes in susceptibility to infections. In: Landy M, Braun W (eds) Bacterial endotoxins, Rutgers University Press, New Brunswick, NJ, pp 359-372.

Tegtmeier B R, Andersen B R 1983 Mechanisms of lipopolysaccharide-induced protection against Pseudomonas sepsis in granulocytopenic mice. Reviews of Infectious Diseases 5 (Suppl): S963-970.

Vaara M, Viljanen P, Vaara T, Mäkelä P H 1984 An outer membrane-disorganizing peptide PMBN sensitizes $E$. coli 
strains to serum bactericidal action. Journal of Immunology 132: $2582-2589$.

Vuopio-Varkila J, Karvonen M, Saxén H 1987a The protective capacity of antibodies to various outer membrane components in a systemic mouse peritonitis model caused by
Escherichia coli O18:K1. Journal of Medical Microbiology. In press.

Vuopio-Varkila J, Nurminen M, Pyhälä L, Mäkelä P H $1987 b$ LPS-induced nonspecific resistance to systemic $E$. coli infection in mice. Journal of Medical Microbiology, 25 : 197203. 